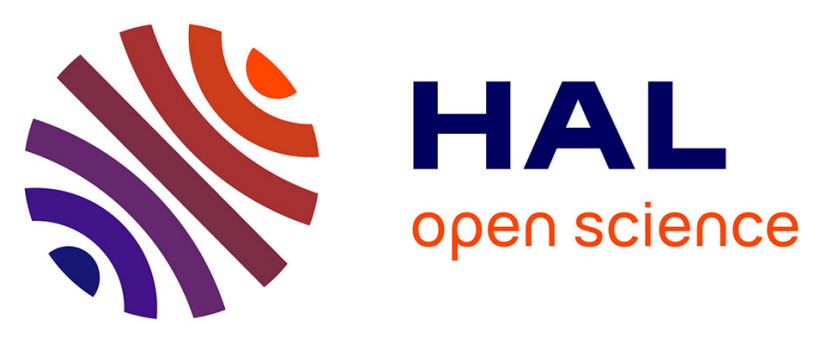

\title{
Contrasting magma types and timing of intrusion in the Permian layered mafic complex of Mont Collon (Western Alps, Valais, Switzerland): evidence from $\mathrm{U} / \mathrm{Pb}$ zircon and 40Ar/39Ar amphibole dating
} Philippe Montjoie, F. Bussy, U. Schaltegger, A. Mulch, Henriette Lapierre, H.-R. Pfeifer

\section{To cite this version:}

Philippe Montjoie, F. Bussy, U. Schaltegger, A. Mulch, Henriette Lapierre, et al.. Contrasting magma types and timing of intrusion in the Permian layered mafic complex of Mont Collon (Western Alps, Valais, Switzerland): evidence from U/Pb zircon and 40Ar/39Ar amphibole dating. Swiss Journal of Geosciences, 2007, 100 (1), pp.125 à 135. 10.1007/s00015-007-1210-8 . insu-00353661

\section{HAL Id: insu-00353661 \\ https://hal-insu.archives-ouvertes.fr/insu-00353661}

Submitted on 23 Nov 2021

HAL is a multi-disciplinary open access archive for the deposit and dissemination of scientific research documents, whether they are published or not. The documents may come from teaching and research institutions in France or abroad, or from public or private research centers.
L'archive ouverte pluridisciplinaire HAL, est destinée au dépôt et à la diffusion de documents scientifiques de niveau recherche, publiés ou non, émanant des établissements d'enseignement et de recherche français ou étrangers, des laboratoires publics ou privés. 


\title{
Contrasting magma types and timing of intrusion in the Permian layered mafic complex of Mont Collon (Western Alps, Valais, Switzerland): evidence from U/Pb zircon and ${ }^{40} \mathrm{Ar} /{ }^{39} \mathrm{Ar}$ amphibole dating
}

\author{
Philippe Monjoie ${ }^{1,2}$, François Bussy ${ }^{1}$, Urs SchaltegGer ${ }^{3}$, Andreas Mulch $^{1,4}$, \\ Henriette LAPIERRE ${ }^{2 \dagger} \&$ HANs-Ruedi Pfeifer ${ }^{1}$
}

Key words: gabbro, mantle, Permian, Western Alps, geochronology

\begin{abstract}
We have selected and dated three contrasting rock-types representative of the magmatic activity within the Permian layered mafic complex of Mont Collon, Austroalpine Dent Blanche nappe, Western Alps. A pegmatitic gabbro associated to the main cumulus sequence yields a concordant $\mathrm{U} / \mathrm{Pb}$ zircon age of $284.2 \pm 0.6 \mathrm{Ma}$, whereas a pegmatitic granite dike crosscutting the latter yields a concordant age of $282.9 \pm 0.6 \mathrm{Ma}$. A Fe-Ti-rich ultrabasic lamprophyre, crosscutting all other lithologies of the complex, yields an ${ }^{40} \mathrm{Ar} /{ }^{39} \mathrm{Ar}$ plateau age of $260.2 \pm 0.7 \mathrm{Ma}$ on a kaersutite concentrate. All ages are interpreted as magmatic. Sub-contemporaneous felsic dikes within the Mont Collon complex are ascribed to anatectic back-veining from the country-rock, related to the emplacement of the main gabbroic body in the continental crust, which is in accordance with new isotopic data. The lamprophyres have isotopic composi-
\end{abstract}

tions typical of a depleted mantle, in contrast to those of the cumulate gabbros, close to values of the Bulk Silicate Earth. This indicates either contrasting sources for the two magma pulses - the subcontinental lithospheric mantle for the gabbros and the underlying asthenosphere for the lamprophyres - or a single depleted lithospheric source with variable degrees of crustal contamination of the gabbroic melts during their emplacement in the continental crust. The Mont Collon complex belongs to a series of Early Permian mafic massifs, which emplaced in a short time span about 285-280 Ma ago, in a limited sector of the post-Variscan continental crust now corresponding to the Austroalpine/Southern Alpine domains and Corsica. This magmatic activity was controlled in space and time by crustal-scale transtensional shear zones.

\section{Introduction}

The Paleozoic Variscan belt in Europe is a result of complex, mainly collisional interactions between Laurussia and Gondwana-derived microcontinents (Stampfli et al. 2002). Early stages of accretion and crustal thickening were followed by post-collisional extension and collapse of the belt during Carboniferous and Permian times. These late- to post-orogenic stages were characterized by high heat flow resulting in high temperature/low pressure metamorphism, widespread crustal anatexis, and the emplacement of large amounts of felsic magmatic rocks, either intrusive or as volcano-sedimentary units in intracontinental basins. Magmatic activity occurred as discrete and short-lived pulses (e.g. Schaltegger 1997; Bussy et al. 2000; Paquette et al. 2003), triggered by mantle upwelling and thermal relaxation of the lithosphere, controlled in space and time by tectonic factors. These dominantly granitic rocks display an evolution through time from high $\mathrm{Mg}-\mathrm{K}$ calc-alkaline to calc-alkaline and finally alkaline affinity. Isotopic data, in particular Nd, point to mantle-crust interactions in the magma sources, with increasing contributions from a depleted mantle (positive $\varepsilon \mathrm{Nd}_{\mathrm{i}}$ ) at the end of the magmatic activity (ca. 280 Ma; Innocent et al. 1994; Monjoie et al. 2002; Paquette et al.

\footnotetext{
${ }^{1}$ Institute of Mineralogy and Geochemistry, IMG-ANTHROPOLE, University of Lausanne, CH-1015 Lausanne (Switzerland). E-mail: francois.bussy@unil.ch

${ }^{2}$ Laboratoire de Géodynamique des Chaînes Alpines LGCA, 1381 rue de la Piscine, University of Grenoble, FR-38041 Grenoble Cedex (France).

${ }^{3}$ Department of Mineralogy, 13, rue des Maraîchers, University of Geneva, CH-1205 Geneva (Switzerland).

${ }^{4}$ current address: Geological and Environmental Sciences, Stanford University, 450 Serra Mall, Building 320, Stanford, CA 94305, USA.

$\dagger$ Deceased January $14^{\text {th }}, 2006$
} 


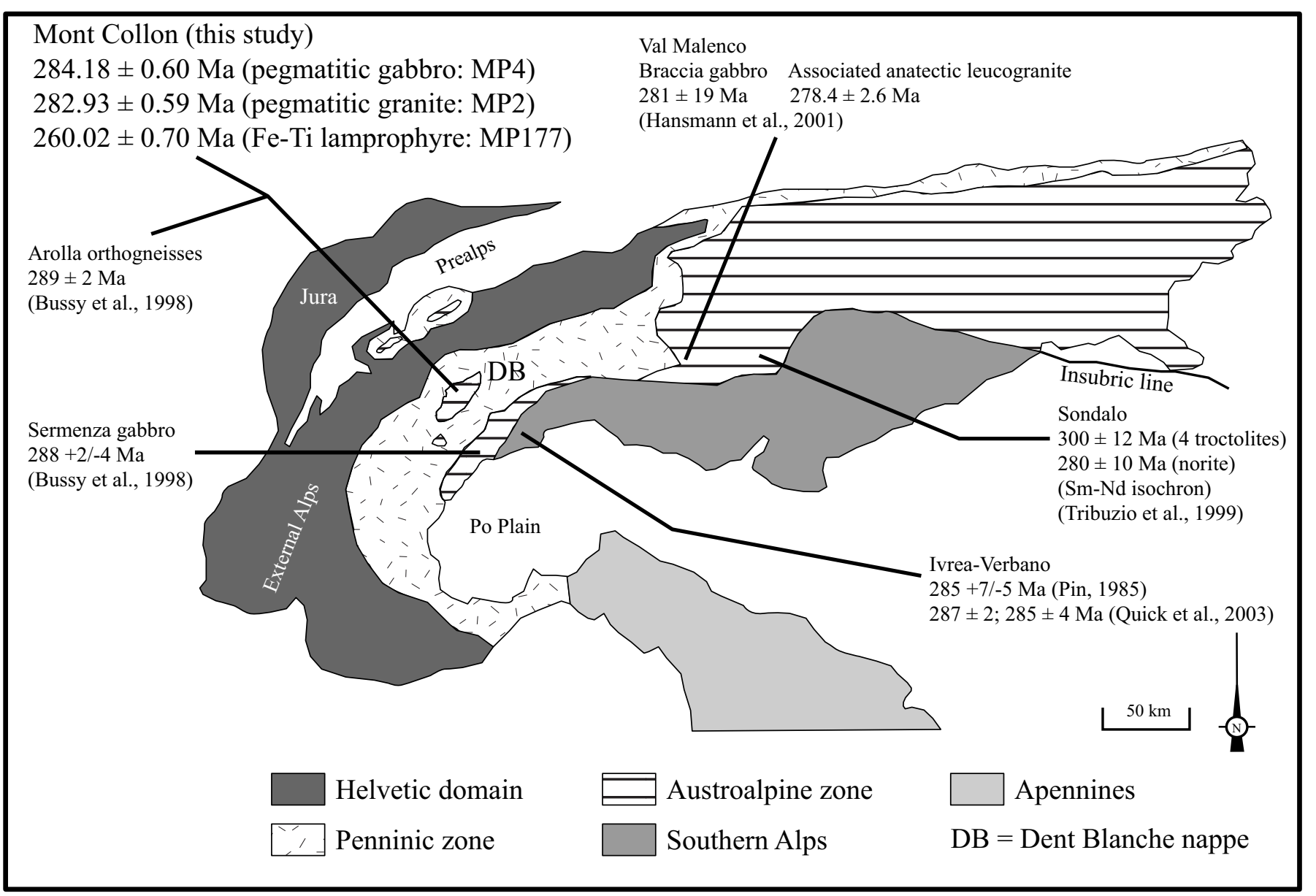

Fig. 1. Distribution of the main Permian Mafic Complexes in the Alpine belt. References for the reported ages: Braccia gabbro (Val Malenco, Hansmann et al., 2001); Sondalo (Tribuzio et al., 1999); Val Anzasca (i.e. Sermenza gabbro in Bussy et al., 1998); Arolla orthogneisses (Bussy et al., 1998); Val Mastallone (Pin, 1986). All ages were determined by $\mathrm{U} / \mathrm{Pb}$ zircon dating except for Sondalo ( $\mathrm{Sm} / \mathrm{Nd}$ isochron ages).

2003; Monjoie 2004). This last magmatic pulse of Early Permian age is tightly connected to large scale transtensional tectonics, accompanied by the formation of volcano-sedimentary basins in the upper crust, and ductile thinning and exhumation of the lower crust (Mulch et al. 2002; Schaltegger \& Brack 2006). Acid and basic magmas were produced contemporaneously, but the latter predominate as large, layered mafic complexes of more or less tholeiitic affinity. These mafic complexes have been documented in the Austroalpine domain of the Alpine belt, in the Southern Alps (Ivrea-Verbano zone) and on Corsica. The Austroalpine occurrences include the following mafic, mostly gabbroic complexes (Fig. 1): Sondalo (Tribuzio et al. 1999), Braccia (Hermann et al. 2001), Mont Collon (Dal Piaz et al. 1977), Anzasca (Sermenza gabbro, Bussy et al. 1998). The Ivrea-Verbano zone hosts the large Ivrea mafic complex (e.g. Quick et al. 1994, 2003; Pin 1986) and associated syntectonic dikes (Mulch et al. 2002), whereas on Corsica several layered bodies are documented (e.g. Fozzano, Poitrasson et al. 1994; Levie and Pila Canale, Paquette et al. 2003).
The Mont Collon mafic complex belongs to the Arolla Series of the Dent Blanche nappe (s.s.); this complex crops out near the village of Arolla, Valais, Switzerland. It is the best preserved of the Permian mafic complexes in the Alps, with remarkably fresh primary mineral assemblages (in particular olivine), very little deformation and minor Alpine metamorphic overprint. Early age determinations for this massif by Dal Piaz et al. (1977) used the K/Ar and Rb/Sr methods on biotite. The data obtained range from $246 \pm 8 \mathrm{Ma}(\mathrm{K} / \mathrm{Ar})$ to $257 \pm 6 \mathrm{Ma}$ $(\mathrm{Rb} / \mathrm{Sr})$ and were interpreted as cooling ages. In general, available ages for the various mafic complexes are of variable quality (e.g. $281 \pm 19 \mathrm{Ma}$ for the Braccia gabbro, Hansmann et al. $2001 ; 285.2 \pm 0.6 \mathrm{Ma}$ for the Levie gabbro-norite, Paquette et al. 2003), but they all seem to point to a single mafic pulse some $285 \mathrm{Ma}$ ago (Fig. 1). The aim of this paper is to provide high precision magmatic ages for contrasting lithologies in the Mont Collon mafic complex in order to verify its affiliation to the above-mentioned group, and more generally to test the apparent synchronism of widespread mantle melting in postVariscan western Europe. 


\section{Geological outline}

In the Western Alps, the Austroalpine system represents the uppermost element of the Europe-vergent Alpine nappe pile (Martinotti \& Hunziker 1984; Ballèvre et al. 1986; Dal Piaz 1993, 1999). This tectonic element comprises several polycyclic basement units of pre-Alpine and Alpine age, and minor monometamorphic Permo-Mesozoic cover units. The Austroalpine System can be subdivided into an eastern and a western sector, the latter being recorded in the Aosta valley (Italy) and southwestern Valais (Switzerland). Many subdivisions have been proposed for the western Austroalpine system (see Venturini et al. 1994; Venturini 1995 and references therein), which basically comprises the Sesia (or Sesia-Lanzo) Zone and the Dent-Blanche System. The latter is a large nappe or klippe, presently disconnected from the Sesia Zone by erosion, but originally linked to it. The complexity of the western Austroalpine system results from the superposition of two major nappe forming events during the Alpine orogeny (Steck et al. 2001). A Late Cretaceous compressive event (eoalpine phase) generated two superposed nappes; the lower nappe of ArollaSesia and the upper nappe of Valpelline-2DK. The subsequent Tertiary tectonic phase (mesoalpine phase) deformed and dismantled this nappe stack, translating part of it westward in a series of tectonic units, including the Dent Blanche nappe, and leaving behind the "root-zone" of Sesia.

The Sesia Zone is limited to the north by Mesozoic ophiolites and associated sediments of the Piemont-Liguria trough, metamorphosed during the Alpine orogeny, now constituting the Zermatt-Saas Zone and Tsaté nappe. These mafic rocks are related to the Jurassic opening of the Tethyan ocean (166 \pm 1 Ma, Bill et al. 1997; $164 \pm 2.7$ Ma, Rubatto et al. 1998; $161 \pm 1$ Ma, Schaltegger et al. 2002) and must be clearly distinguished from the continental mafic magmatism of Permian age addressed in this work. To the south, the Sesia Zone is bounded by the southern Alpine Ivrea-Verbano Zone, from which it is separated by the Insubric line (Fig. 1). The Ivrea-Verbano Zone consists of slices of ultramafic rocks in contact with lithologies metamorphosed during the Variscan orogeny in the amphibolite to granulite facies, as well as Early Permian mafic intrusions (Schaltegger \& Brack 2006 and references therein). The inferred paleogeographic position of the units described above was, from NW to SE (Steck et al. 2001): (1) the Briançonnais domain (s.l.); (2) the Piemont-Liguria ocean, opened during the Dogger; (3) the Austroalpine domain, constituting the northern margin of the Adriatic plate; (4) the Canavese bassin, opened during the Lias within the Adriatic plate; (5) the Southern Alpine domain, represented by the Ivrea-Verbano Zone. The eoalpine phase of compression closed the Canavese basin in the Late Cretaceous. It induced the SE directed subduction of the Sesia Zone underneath the main body of the Adriatic plate $76 \mathrm{Ma}$ ago (Gebauer 1999), reaching maximum burial under $\mathrm{HP}$ metamorphic conditions $65 \mathrm{Ma}$ ago (Gebauer 1999). The mesoalpine tectonic phase closed the Piemont-Liguria ocean during the Eocene, subduct- ed the Zermatt-Saas Zone and induced the nappe stack currently observed in the Alpine belt.

The Sesia zone consists of polycyclic metamorphic rocks derived from pre-Alpine lithologies (mainly high grade paragneiss, granulite and amphibolite) into which intruded kilometer-size bodies of Upper Carboniferous calc-alkaline quartzdiorite to granite. The Alpine orogeny reworked these protoliths according to regionally different P-T-t paths. In the southwestern part of the Sesia-zone, 65 Ma-old eclogites and blueschist facies rocks occur, whereas in the northwestern part, the so-called "Gneiss Minuti unit" shows intense greenschist metamorphism and deformation.

The Dent-Blanche System is subdivided into a northern upper part (the Dent-Blanche nappe s.s., Mont Mary and Pillonet klippen) and a southern lower part (Monte EmiliusGlacier Raffray-Tour Ponton units) by the Aosta Valley and the east-west-trending Aosta-Ranzola fault system (Bistacchi et al. 2001). The Alpine metamorphic overprint is of greenschist grade north of the Aosta valley and eclogitic south of this valley (including the Mont Emilius klippe). The basement of the Dent-Blanche Nappe s.s. is composed of two tectonic elements resulting from the eoalpine tectonic phase: the lower Arolla and upper Valpelline nappes or series. The Arolla series, consisting of the same lithologies as the polycyclic basement rocks of the Sesia unit, hosts the large mafic bodies of Mont Collon and Matterhorn (Dal Piaz et al. 1977).

\section{Field relationships, geochemistry and petrology}

The Mont Collon mafic complex consists of three major exposures and several small scattered outcrops, which are partly hidden by large glaciers (Mont Collon, Arolla and Ferpècle glaciers) and their moraines. This mafic complex is in tectonic contact with calc-alkaline metagranitoids (orthogneisses) and paragneisses of the Arolla series. The meter-thick contact zone is clearly mylonitic to blastomylonitic, deforming both country rock and mafic lithologies. For this reason we cannot establish whether or not the Arolla orthogneiss is the original country rock of the Mont Collon mafic body.

About 95 vol.-\% of this complex are coarse-grained olivine- and/or clinopyroxene-bearing gabbroic cumulates, well exposed in the Dents de Bertol area (Dal Piaz et al. 1977; Monjoie 2004; Monjoie et al. 2005). Cumulitic textures are underlined by preferred mineral orientation. Olivine (Fo79-74) and diopsidic clinopyroxene $\left(\mathrm{Mg \#} \#_{\mathrm{cpx}} \approx 85 ; \mathrm{Al}_{2} \mathrm{O}_{3}<3.1 \mathrm{wt} \%\right.$ ) form the main cumulus phases, crystallized as $2-3 \mathrm{~mm}$ long euto subhedral grains. Plagioclase (An83-63) forms tabular crystals, commonly with parallel alignment. Late-magmatic Ti-rich pargasite (up to $3.5 \mathrm{wt} \% \mathrm{TiO}_{2}$ ) dominates the intercumulus assemblage, occurring as overgrowths or patches surrounding clinopyroxene. Accessory minerals (magnetite, ilmenite, sulphides and apatite) are rare in all lithologies. No major variation is observed in the mineral chemistry over the cumulitic gabbro sequence (Monjoie et al. 2005). 
Table 1. Major- (wt\% oxides) and trace-element (ppm) concentrations of the dated samples. Trace-element concentrations were measured by liquid mode ICP-MS on a FISONS VG PlasmaQuad PQ+ apparatus at the University of Grenoble. Trace-elements (*: classical analysis mode, **: Rhodes long-time analysis mode) and major-elements were measured by XRF on a Philips PW2400 instrument at the University of Lausanne. $\mathrm{mg} \#=(100 * \mathrm{Mg} /(\mathrm{Mg}+\mathrm{Fe}))$.

\begin{tabular}{|c|c|c|c|}
\hline Rock types & $\begin{array}{l}\text { pegmatitic } \\
\text { gabbro }\end{array}$ & $\begin{array}{l}\text { pegmatitic } \\
\text { granite }\end{array}$ & Fe-Ti lamprophyre \\
\hline Sample numbers & MP4 & MP2 & MP177 \\
\hline $\mathrm{SiO}_{2}$ & 50.6 & 61.0 & 41.6 \\
\hline $\mathrm{TiO}_{2}$ & 0.53 & 0.14 & 3.32 \\
\hline $\mathbf{A l}_{2} \mathrm{O}_{3}$ & 17.4 & 22.1 & 12.2 \\
\hline $\mathrm{FeO}_{\mathbf{T}}$ & 5.5 & 0.87 & 14.2 \\
\hline MnO & 0.12 & 0.01 & 0.19 \\
\hline MgO & 8.4 & 0.63 & 10.5 \\
\hline $\mathrm{CaO}$ & 11.8 & 6.7 & 10.2 \\
\hline $\mathrm{Na}_{2} \mathrm{O}$ & 2.79 & 5.59 & 2.90 \\
\hline $\mathbf{K}_{2} \mathbf{O}$ & 0.73 & 1.48 & 0.51 \\
\hline $\mathbf{P}_{2} \mathbf{O}_{5}$ & 0.07 & 0.11 & 0.72 \\
\hline LOI & 1.7 & 1.3 & 2.8 \\
\hline Total & 99.68 & 100.05 & 99.14 \\
\hline Mg\# & 73.1 & 56.5 & 56.9 \\
\hline $\mathbf{C u} *$ & 18 & 6 & 61 \\
\hline $\mathbf{S}^{*}$ & 69 & 80 & 1351 \\
\hline Sc* & 35 & 7 & 34 \\
\hline $\mathbf{V}^{* *}$ & 110 & 15 & 267 \\
\hline $\mathrm{Cr}^{* * *}$ & 233 & 8 & 256 \\
\hline $\mathbf{N i}^{* * *}$ & 54 & 14 & 246 \\
\hline $\mathbf{G a}^{* *}$ & 16 & 26 & 24 \\
\hline $\mathbf{Z n} * *$ & 178 & 16 & 131 \\
\hline Co & 36 & 13 & 50 \\
\hline Cs & 0.36 & 0.82 & 0.43 \\
\hline $\mathbf{R b}$ & 29.6 & 47.2 & 2.6 \\
\hline $\mathbf{B a}$ & 188.4 & 275.2 & 92.2 \\
\hline Th & 0.90 & 14.67 & 3.84 \\
\hline $\mathbf{U}$ & 0.70 & 0.88 & 1.30 \\
\hline Nb & 3.56 & 11.50 & 69.98 \\
\hline Ta & 0.23 & 0.66 & 3.94 \\
\hline $\mathbf{P b}$ & 38.18 & 6.07 & 2.01 \\
\hline $\mathbf{S r}$ & 503.9 & 492.3 & 442.9 \\
\hline $\mathbf{Z r}$ & 20.9 & 20.0 & 290.2 \\
\hline Hf & 0.67 & 0.60 & 5.87 \\
\hline $\mathbf{Y}$ & 16.1 & 4.0 & 29.8 \\
\hline La & 6.11 & 61.40 & 35.44 \\
\hline $\mathrm{Ce}$ & 15.36 & 108.64 & 72.77 \\
\hline Pr & 2.18 & 11.13 & 9.06 \\
\hline Nd & 9.39 & 35.46 & 37.99 \\
\hline Sm & 2.48 & 4.58 & 8.20 \\
\hline Eu & 0.77 & 1.41 & 2.54 \\
\hline Gd & 2.60 & 2.45 & 7.69 \\
\hline $\mathbf{T b}$ & 0.43 & 0.25 & 1.13 \\
\hline Dy & 2.51 & 0.87 & 5.73 \\
\hline Нo & 0.51 & 0.13 & 1.02 \\
\hline $\mathbf{E r}$ & 1.41 & 0.32 & 2.60 \\
\hline $\mathbf{Y b}$ & 1.14 & 0.25 & 1.93 \\
\hline Lu & 0.17 & 0.04 & 0.26 \\
\hline
\end{tabular}

Other facies of interest consist of sills of wehrlite parallel to the gabbro layering, as well as a few meter-sized pockets of pegmatitic gabbros. The latter are randomly distributed in the massif, representing the only mafic facies without cumulitic features. At the base of the Mont Collon summit, there is a progressive and continuous transition from cumulitic to pegmatitic texture. This relationship evidences that the gabbro cumulates and pegmatites are contemporaneous. The pegmatitic gabbros have well preserved magmatic textures, although they recrystallized under greenschist facies conditions. They now consist of large crystals (up to several $\mathrm{cm}$ long) of albitic plagioclase and of polycrystalline aggregates of pale green secondary actinolite. Fe-oxides are scarce and represent less than 1 vol.- \%.

Whole-rock major- and trace-element chemical composition of the gabbros is dominantly controlled by the nature and proportions of the cumulus mineral phases, and secondarily by interstitial residual melt (Monjoie 2004; Monjoie et al. 2005). The parental melt modeled from the REE composition of cumulitic clinopyroxene is characterized by relative enrichment in LREE $\left(2.45<\mathrm{La}_{\mathrm{N}} / \mathrm{Yb}_{\mathrm{N}}<4.15\right)$, reminiscent of transitional basalt (T-MORB). Initial ${ }^{87} \mathrm{Sr} /{ }^{86} \mathrm{Sr}_{i}$ ratios of $0.70449-0.70567$, $\varepsilon \mathrm{Nd}_{\mathrm{i}}$ values of +3.2 to -0.6 , and $\mathrm{Pb}$ isotopic ratios close to those of Bulk Silicate Earth (BSE), together with trace-element constraints led Monjoie (2004) to postulate a metasomatized lithospheric mantle as the source of the Mont Collon gabbros. The whole-rock chemistry of pegmatitic gabbros does not significantly differ from that of the dominant olivine- and clinopyroxene-gabbros. They display similar $\mathrm{FeO}_{\mathrm{T}}$ and $\mathrm{Al}_{2} \mathrm{O}_{3}$ contents, are enriched in $\mathrm{TiO}_{2}, \mathrm{Na}_{2} \mathrm{O}$ and $\mathrm{K}_{2} \mathrm{O}$ and depleted in $\mathrm{CaO}$.

The Mont Collon gabbro is crosscut by numerous centimeter- to decimeter-sized leucocratic dikes of anorthosite, granodiorite and granite (aplitic and pegmatitic). Feldspar is usually sericitized, biotite is present in the granodiorites, and apatite is abundant (up to 5 vol.-\%) in the anorthosites together with some amphibole. The granitoid dikes are characterized by low $\varepsilon \mathrm{Nd}_{\mathrm{i}}$ values of -1 to -6.6 , high initial ${ }^{87} \mathrm{Sr} /{ }^{86} \mathrm{Sr}_{\mathrm{i}}$ ratios of 0.70573 to 0.71005 , and $\mathrm{Pb}$ isotopes close to the EMII end-member, all pointing to a continental crust origin. Monjoie (2004) interpreted these granitoid dikes as resulting from back-veining of anatectic melts generated in the country-rock during intrusion of the mafic complex in the middle crust. Conversely, the anorthositic dikes are considered residual melts segregated from the main gabbroic cumulate sequence.

A few dark, fine-grained, Fe-Ti-rich lamprophyric dikes crosscut all other lithologies and represent the latest magmatic event of the Mont Collon complex. They are restricted to the Dents de Bertol area and have never been found in the country rock. Similar lamprophyres have been described by Dal Piaz et al. (1977) in the neighboring Matterhorn mafic body. They are composed of Fe-Ti-rich (Table 1) kaersutite (55-60 vol.- $\%)$, diopside (6-8 vol.- \%) and interstitial albite (25-28 vol.- $\%)$ associated with apatite $(\sim 2$ vol.- $\%)$ and Fe-Ti oxides (magnetite and ilmenite, 3-5 vol.-\%). Calcite commonly crystallized in thin veins.

The Fe-Ti lamprophyres are $\mathrm{SiO}_{2}$-undersaturated (40.7-43.1 wt \%) and nepheline normative ( $n e=6.5-9.0 \%$ ). They contain about $12 \mathrm{wt} \% \mathrm{FeO}_{\mathrm{T}}$ and they are especially rich in $\mathrm{TiO}_{2}$, alkalis, $\mathrm{P}_{2} \mathrm{O}_{5}$ and $\mathrm{REE}\left(\Sigma \mathrm{REE}_{\mathrm{N}} \sim 700\right.$; Table 1$)$. Their 
trace-element contents are very similar to those of within-plate alkaline mafic rocks. The lamprophyric dikes have the highest $\varepsilon \mathrm{Nd}_{\mathrm{i}}$ values $(+7.4)$ and lowest ${ }^{87} \mathrm{Sr} /{ }^{86} \mathrm{Sr}_{\mathrm{i}}$ ratio (0.703) in the Mont Collon igneous suite, whereas $\mathrm{Pb}$ isotopic values are close to those of MORBs (Monjoie 2004), all suggesting a depleted mantle source without involvement of the continental crust.

Thermo-barometric conditions of crystallization for the main layered units of the Mont Collon complex have been estimated at $1070-1120^{\circ} \mathrm{C}$ and 0.5 to $0.7 \mathrm{GPa}$, respectively (Monjoie 2004), pointing to a mid-crustal depth of intrusion for the magmatic chamber. Conversely, the occurrence of fine-grained margins, miarolitic vesicles and acicular apatite in the lamprophyric dikes suggest rapid cooling at shallower depth.

\section{Analytical procedures}

Zircons were extracted from rock samples according to the procedure described in Bussy \& Cadoppi (1996). Selected crystals were air-abraded (Krogh 1973) and separation of $U$ and $\mathrm{Pb}$ follows the procedure of Schaltegger et al. (1999). Isotopic measurements were done on a Finnigan MAT262 mass spectrometer at ETH (Zurich). Data reduction was done using the unpublished ROMAGE program of Davis (University of Toronto) and the ISOPLOT software of Ludwig (Excel version 2.06, 1998). Data were corrected for ${ }^{230} \mathrm{Th}$ discrimination in crystallizing zircon (Schärer 1984) using a model magmatic $\mathrm{Th} / \mathrm{U}$ ratio of 4 . Errors are reported at the $95 \%$ confidence level. Decay constants are those reported by Jaffrey et al. (1971).

${ }^{40} \mathrm{Ar} /{ }^{39} \mathrm{Ar}$ dating was performed on a $20-30 \mathrm{mg}$ sample of manually selected amphibole. Samples and closely spaced standards were irradiated for 20 hours in the central thimble position of the USGS TRIGA reactor in Denver (CO), USA (Dalrymple et al. 1981). The neutron flux was monitored using the standard MMHB-1 assuming an age of $523.1 \pm 4.6 \mathrm{Ma}$ (Renne et al. 1998). The J value for the irradiation was 0.00301 \pm 0.0001 for bulk mineral separates. Furnace step-heating analyses were performed using a double vacuum resistance furnace. After furnace step-heating, the gas was exposed to a metal cold finger at temperatures of approximately $-130^{\circ} \mathrm{C}$ and cleansed using an SAES AP50 getter for an additional $180 \mathrm{sec}$ onds to remove all active gases. Following cleanup the gas was expanded into a modified MAP 215-50 mass spectrometer for isotopic analysis. Eight scans per analysis were made over the mass range of 40 to 36 and peak heights extrapolated back to inlet time. Furnace blanks ranged for $\mathrm{m} / \mathrm{e}=40$ from $2 \times 10^{-14}$

Fig. 2. a) Field relationship between MP4 (pegmatitic gabbro) and MP2 (pegmatitic granite) on the northern wall of the Mont Collon, b) example of Fe-Ti lamprophyric dike (located on the Dents de Bertol), c) microscopic view of the Fe-Ti lamprophyric dike MP177 (kaer=kaersutite, $\mathrm{cpx}=$ clinopyroxene, $\mathrm{plg}=$ plagioclase $\left(\mathrm{An}_{3-15}\right)$, ox=Fe-Ti oxides $)$.
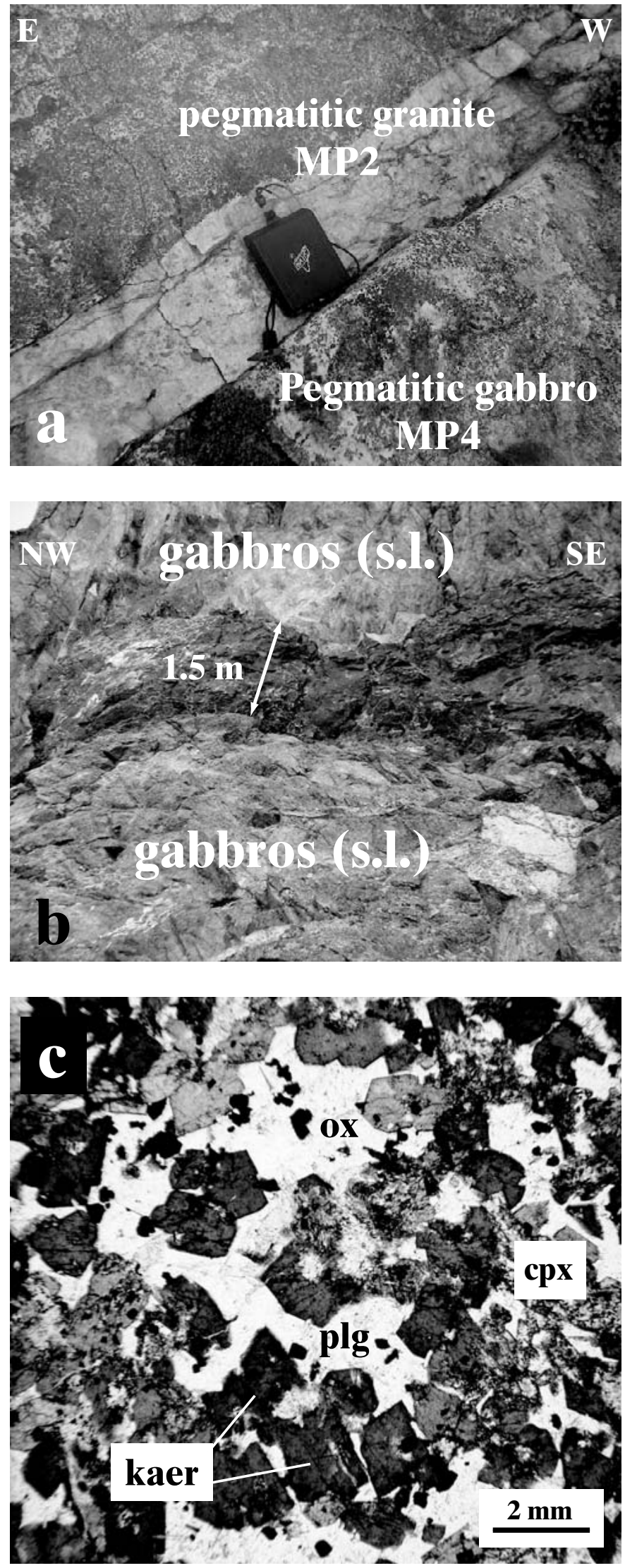


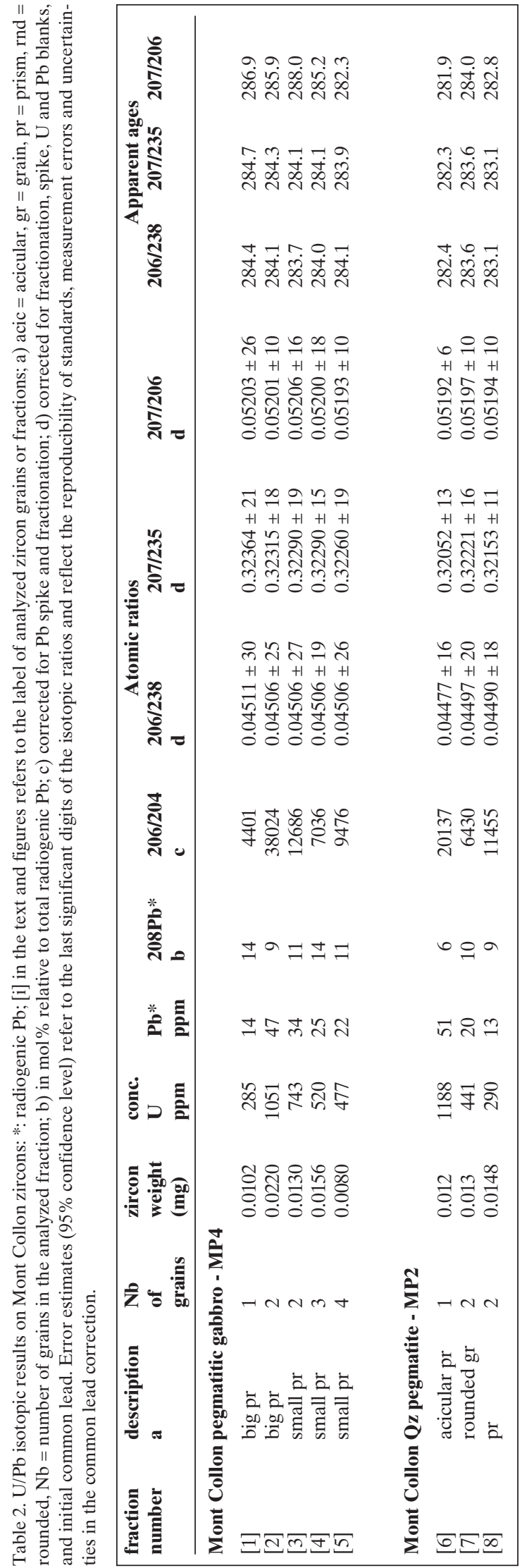

moles at $1500^{\circ} \mathrm{C}$ to $5 \times 10^{-15}$ moles below $1000^{\circ} \mathrm{C}$. Blank values for $\mathrm{m} / \mathrm{e}=36-39$ were below $2 \times 10^{-16}$ moles. Peak heights were corrected for background, mass discrimination, and for decay of interfering isotopes of argon derived from $\mathrm{Ca}, \mathrm{K}$, and $\mathrm{Cl}$. The apparent ages were calculated using an assumed initial ${ }^{40} \mathrm{Ar} /{ }^{36} \mathrm{Ar}$ ratio of 295.5 and decay constants recommended by Steiger \& Jäger (1977).

\section{Sample description}

Zircon grains were extracted from a $60 \mathrm{~kg}$ sample of pegmatitic gabbro and from a $10 \mathrm{~kg}$ sample of (quartz-rich) pegmatitic granite dike crosscutting the latter (Fig. 2a), both collected on the northern edge of the Mont Collon. The pegmatitic gabbro MP4 (Swiss coordinates: 605.500/092.800) partly recrystallized under greenschist facies conditions, but still preserves a magmatic texture. It consists of several $\mathrm{cm}$ long crystals of plagioclase and pale green polycrystalline aggregates of actinolite, probably replacing magmatic amphibole. Fe-oxides are scarce $(<1$ vol.- $\%)$. Most of the 250 zircons recovered from sample MP4 were transparent, pinkish, subhedral, stubby prisms, up to 120 microns in length, often cracked and rich in inclusions. Five fractions consisting of one to five gem-quality grains were selected and analyzed ([1]-[5]; Table 2).

The pegmatitic granite MP2 (coord.: 605.750/093.420) (Fig. 2a) is a dm-thick dike with strong intracrystalline deformation, mainly composed of K-feldspar (Or96; up to $5 \mathrm{~cm}$ ) and quartz. Three zircon fractions ([6]-[8]; Table 2), consisting of one or two prismatic grains each, were selected from this sample.

An ultrabasic Fe-Ti lamprophyric dike MP177 (Fig. 2b and c) was collected from the Dent de Bertol area (coord.: 606.440/093.670) for ${ }^{40} \mathrm{Ar} /{ }^{39} \mathrm{Ar}$ amphibole dating. It consists of euhedral kaersutite (55-60 vol.- \%, see mineral composition in Table 4), ilmenite (3-5 vol.- \%), titanite, diopside (6-8 vol.- \%), and interstitial Na-rich plagioclase (25-28 vol.-\%; Ab94.595.2 $\mathrm{An}_{4.5-5.2} \mathrm{Or}_{0.1-0.2)}$; a mineral assemblage typical of alkaline hydrous melts. The albitic composition is surprising, considering the chemistry of these dikes (Table 1), thus plagioclase may be secondary in origin. Whole-rock major- and traceelement chemical analyses for all three of the dated samples are reported in Table 1.

\section{Isotopic results}

All zircon fractions from the gabbro sample MP4 are perfectly concordant and overlapping ([1]-[5]; Table 2 and Fig. 3a) at a mean Concordia age of $284.2 \pm 0.6 \mathrm{Ma}$ (probability of concordance 0.57 ), interpreted as the crystallization age of the pegmatitic gabbro.

The three zircon fractions from the pegmatitic granite dike MP2 yield concordant data, which overlap within errors ([6]-[8]; Table 2 and Fig. 3b), with a mean Concordia age of $282.9 \pm 0.6 \mathrm{Ma}$ (probability of concordance 0.94 ). This age is 

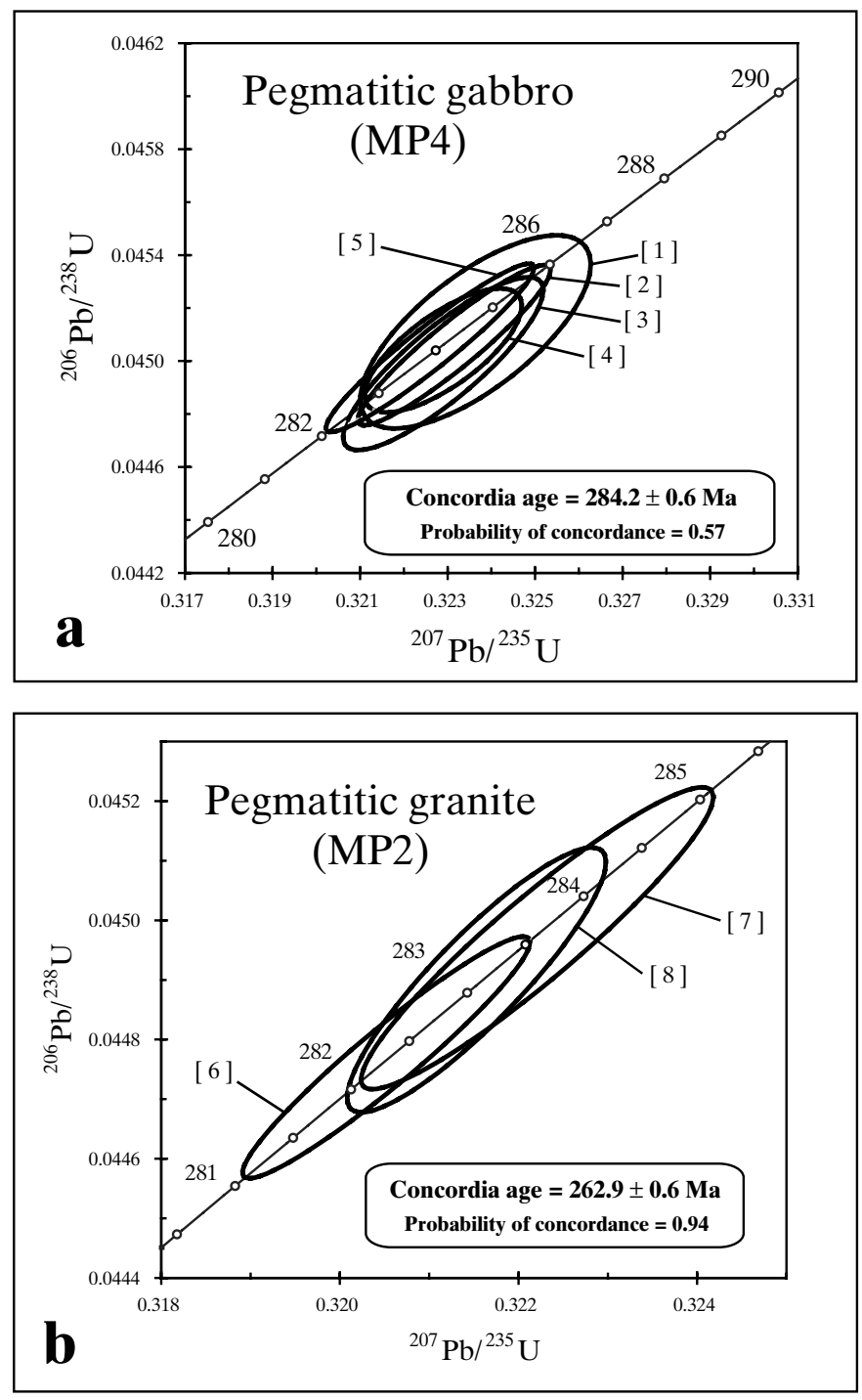

Fig. 3. U/Pb Concordia diagram for a) pegmatitic gabbro from the Mont Collon northern face; b) pegmatitic granite from the Dents de Bertol southern wall. Error ellipses are given at the $95 \%$ confidence level. Numbers in [ ] refer to the mineral fractions listed in Table 2. See discussion in the text.

interpreted as the crystallization time of the acidic dike. Zircons show no evidence of inheritance in the two samples. The error ellipses for the two ages are contiguous; the pegmatitic gabbro yielding the older age, in accordance with the crosscutting relationships observed in the field.

An integrated age of $255.4 \pm 2.0$ Ma can be calculated from the amphibole concentrate of the lamprophyric dike MP177 (Table 3, Fig. 4). The first eight heating steps differ markedly (higher $\mathrm{Ca} / \mathrm{K}$ ratios) from gas released during the remaining steps. These high $\mathrm{Ca} / \mathrm{K}$ ratios are interpreted as the degassing of a contaminant phase with a higher $\mathrm{Ca} / \mathrm{K}$ ratio than bulk amphibole. Excluding these first steps for age calculation, we obtain a plateau age of $260.2 \pm 0.7 \mathrm{Ma}$, which is considerably

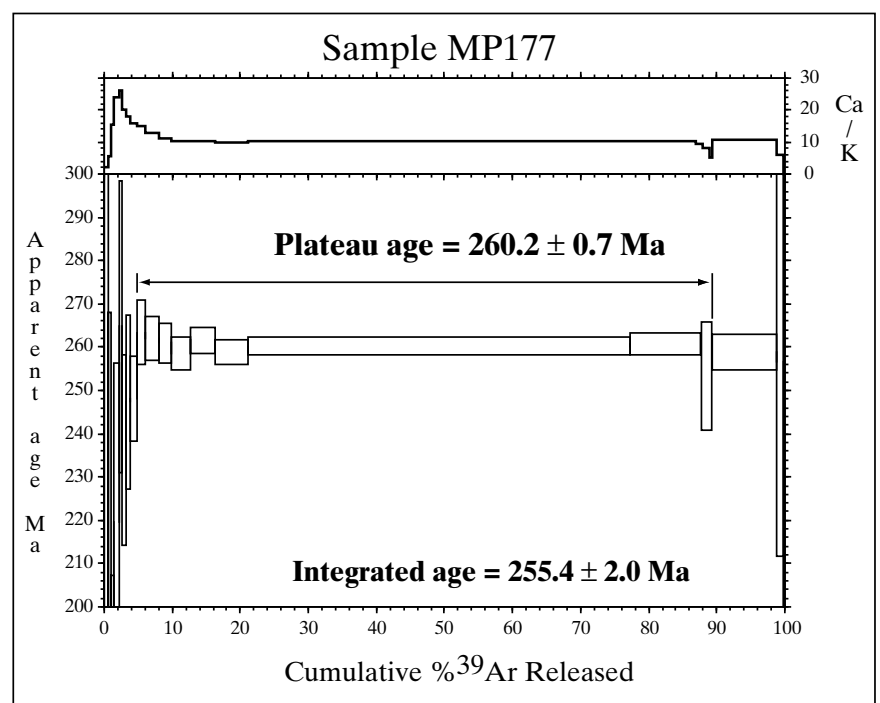

Fig. 4. $\mathrm{Ca} / \mathrm{K}$ and ${ }^{40} \mathrm{Ar} /{ }^{39} \mathrm{Ar}$ step-heating spectrum vs. cumulative $\%{ }^{39} \mathrm{Ar}$ released diagram for lamprophyric dike MP177.

younger than the $\mathrm{U} / \mathrm{Pb}$ zircon ages obtained for the gabbros and acidic dikes. This age could either be considered as a cooling age reflecting the passage of the rock through the 450 to $500^{\circ} \mathrm{C}$ temperature interval (McDougall \& Harrison 1988) or reflect the timing of crystallization of the dike within (relatively) shallow crustal levels. Even though intrinsic mineral parameters such as effective grain size, diffusion length scale and $\mathrm{Mg}$ content of the MP177 kaersutites $(\mathrm{MgO}=9.85-11.82$ wt \%; Table 4) potentially affect the absolute closure temperature by changing the diffusion properties, our interpretations do not rely on the absolute temperature at which Ar diffusion effectively ceased in the mineral. Pressure calculations point to a mid-crustal level of emplacement for the main cumulitic facies, whereas textural and petrographic characteristics of the lamprophyric dikes (i.e. miarolitic voids indicating fluid exsolution, apatite needles, fine grain-size and chilled margins) suggest rapid crystallization of the magma in a relatively cold environment, most likely at much shallower depth. Hence, fast cooling of the dike after emplacement suggests that cooling and crystallization age are likely to be very similar. Consequently, the obtained ${ }^{40} \mathrm{Ar} /{ }^{39} \mathrm{Ar}$ age of $260 \mathrm{Ma}$ is probably very close to the age of magmatic crystallization of the dikes, which implies that the lamprophyric magmatism recorded in the Mont Collon is some 25 Ma younger than the crystallization of the main gabbroic body.

\section{Discussion}

The dated pegmatitic gabbro, chosen for its high probability of hosting zircon, is considered to be contemporaneous with the main cumulate sequence, on the basis of field relationships. The transition between the layered facies and the pegmatitic 
Table 3. Analytical data of ${ }^{40} \mathrm{Ar} /{ }^{39} \mathrm{Ar}$ incremental heating age determinations of amphiboles from Fe-Ti lamprophyric dike MP177

\begin{tabular}{|c|c|c|c|c|c|c|c|c|}
\hline \multicolumn{2}{|c|}{${ }^{40} \mathrm{Ar} *{ }^{39} \mathrm{Ar}$} & $\begin{array}{l}{ }^{36} \mathrm{Ar} / 40 \mathrm{Ar} \\
\times 1000\end{array}$ & ${ }^{39} \mathrm{Ar} /{ }^{40} \mathrm{Ar}$ & ${ }^{37} \mathrm{Ar} /{ }^{39} \mathrm{Ar}$ & ${ }^{38} \mathrm{Ar} /{ }^{39} \mathrm{Ar}$ & $\%^{39} \mathrm{Ar}$ & Age & $2 \sigma$ \\
\hline \multirow{2}{*}{\multicolumn{2}{|c|}{$\begin{array}{l}\text { MP177 amphibole } \\
\text { Run number }\end{array}$}} & \multicolumn{7}{|l|}{$\mathbf{J}=\mathbf{0 . 0 0 3 0 1}$} \\
\hline & & & & & & & & \\
\hline 1 & 1.429 & 3.380 & 0.001 & 0.990 & 0.953 & 0.08 & 7.7 & 435.2 \\
\hline 2 & 4.604 & 3.373 & 0.001 & 2.786 & 0.973 & 0.08 & 24.8 & 243.2 \\
\hline 3 & 23.336 & 3.254 & 0.002 & 7.921 & 0.604 & 0.17 & 122.5 & 84.7 \\
\hline 4 & 43.038 & 2.955 & 0.003 & 12.313 & 0.511 & 0.30 & 219.8 & 36.7 \\
\hline 5 & 52.507 & 2.796 & 0.004 & 13.331 & 0.481 & 0.33 & 264.7 & 33.8 \\
\hline 6 & 46.499 & 2.641 & 0.005 & 10.231 & 0.379 & 0.47 & 236.3 & 22.0 \\
\hline 7 & 48.822 & 2.413 & 0.006 & 9.141 & 0.334 & 0.58 & 247.4 & 20.0 \\
\hline 8 & 48.974 & 2.067 & 0.008 & 8.071 & 0.273 & 0.76 & 248.1 & 9.9 \\
\hline 9 & 52.232 & 1.799 & 0.009 & 7.693 & 0.234 & 0.86 & 263.4 & 7.5 \\
\hline 10 & 51.921 & 1.511 & 0.011 & 6.458 & 0.175 & 1.01 & 262.0 & 5.1 \\
\hline 11 & 51.713 & 1.378 & 0.012 & 5.771 & 0.151 & 1.09 & 261.0 & 4.6 \\
\hline 12 & 51.168 & 1.147 & 0.013 & 5.338 & 0.125 & 1.22 & 258.4 & 3.8 \\
\hline 13 & 51.833 & 0.930 & 0.014 & 5.202 & 0.107 & 1.31 & 261.6 & 3.1 \\
\hline 14 & 51.280 & 0.753 & 0.016 & 5.057 & 0.096 & 1.41 & 259.0 & 2.8 \\
\hline 15 & 51.546 & 0.318 & 0.018 & 5.279 & 0.092 & 1.61 & 260.2 & 2.0 \\
\hline 16 & 51.639 & 0.853 & 0.015 & 5.227 & 0.095 & 1.35 & 260.6 & 2.5 \\
\hline 17 & 50.094 & 2.270 & 0.007 & 4.882 & 0.138 & 0.64 & 253.4 & 12.5 \\
\hline 18 & 47.462 & 2.760 & 0.004 & 4.189 & 0.198 & 0.39 & 240.9 & 24.1 \\
\hline 19 & 35.286 & 3.081 & 0.003 & 2.714 & 0.279 & 0.25 & 182.1 & 66.3 \\
\hline 20 & 51.248 & 1.644 & 0.010 & 5.505 & 0.110 & 0.96 & 258.8 & 4.2 \\
\hline 21 & 50.756 & 3.058 & 0.002 & 3.157 & 0.353 & 0.19 & 256.5 & 44.7 \\
\hline 22 & 12.738 & 3.365 & 0.000 & 0.000 & 1.417 & 0.04 & 67.9 & 1093.4 \\
\hline
\end{tabular}

Table 4. Selected electron microprobe analyses (wt \%) of kaersutite (classification of Leake et al., 1997) from lamprophyre sample MP177 (wt\%) used for ${ }^{40} \mathrm{Ar}{ }^{39} \mathrm{Ar}$ dating. Normalization scheme based on $\mathrm{Si}+\mathrm{Al}+\mathrm{Ti}+\mathrm{Fe}+\mathrm{Mn}+$ $\mathrm{Mg}=13$ cations.

\begin{tabular}{|lrrrrr|}
\hline $\mathbf{S i O}_{2}$ & 39.81 & 38.82 & 38.35 & 39.13 & 38.52 \\
$\mathbf{T i O}_{2}$ & 4.91 & 5.52 & 6.79 & 5.62 & 6.08 \\
$\mathbf{A l}_{2} \mathbf{O}_{3}$ & 12.81 & 13.07 & 13.46 & 13.22 & 13.33 \\
$\mathbf{F e O}$ & 15.20 & 13.21 & 12.60 & 12.25 & 11.94 \\
$\mathbf{M n O}$ & 0.29 & 0.22 & 0.21 & 0.20 & 0.24 \\
$\mathbf{M g O}$ & 9.85 & 10.93 & 10.87 & 11.52 & 11.35 \\
$\mathbf{C a O}$ & 11.13 & 11.30 & 11.59 & 11.16 & 11.14 \\
$\mathbf{N a} \mathbf{O}$ & 2.79 & 2.67 & 2.56 & 2.86 & 2.78 \\
$\mathbf{K}_{2} \mathbf{O}$ & 1.07 & 1.20 & 1.17 & 1.17 & 1.12 \\
$\mathbf{T o t a l}$ & 97.86 & 96.94 & 97.60 & 97.13 & 96.50 \\
\hline $\mathbf{S i}$ & 6.00 & 5.87 & 5.76 & 5.87 & 5.79 \\
$\mathbf{A l} \mathbf{I}^{\mathbf{I V}}$ & 2.00 & 2.13 & 2.24 & 2.13 & 2.21 \\
$\mathbf{A l}{ }^{\mathbf{V I}}$ & 0.27 & 0.20 & 0.14 & 0.20 & 0.15 \\
$\mathbf{T i}$ & 0.56 & 0.63 & 0.77 & 0.63 & 0.69 \\
$\mathbf{F e}$ & 1.92 & 1.67 & 1.58 & 1.54 & 1.50 \\
$\mathbf{M n}$ & 0.04 & 0.03 & 0.03 & 0.03 & 0.03 \\
$\mathbf{M g}$ & 2.21 & 2.46 & 2.43 & 2.57 & 2.54 \\
$\mathbf{C a}$ & 1.80 & 1.83 & 1.86 & 1.79 & 1.79 \\
$\mathbf{N a}$ & 0.82 & 0.78 & 0.75 & 0.83 & 0.81 \\
$\mathbf{K}$ & 0.21 & 0.23 & 0.22 & 0.22 & 0.21 \\
$\mathbf{T o t a l}$ & 15.83 & 15.83 & 15.78 & 15.81 & 15.72 \\
\hline
\end{tabular}

pockets is progressive and of magmatic type, without evidence of cold or brittle contact. Moreover, $\mathrm{Sr}$ and $\mathrm{Nd}$ isotopic characteristics of the pegmatitic gabbro and the main layered facies are very similar, suggesting a common source. In other words, the large magmatic chamber of Mont Collon was emplaced in the middle crust at $284.2 \pm 0.6 \mathrm{Ma}$, presumably in multiple pulses, as documented by small isotopic variations in the cumulate sequence (Monjoie 2004). The numerous granitoid dikes crosscutting the mafic lithologies crystallized shortly after, as indicated by the age of $282.9 \pm 0.6 \mathrm{Ma}$ obtained for the pegmatitic granitoid dike MP2. The relationship between the Mont Collon complex and its present-day country rock (i.e. the Arolla orthogneisses) remains unclear, as they are separated by a continuous mylonitic zone. Bussy et al. (1998) dated the Arolla orthogneisses at $289 \pm 2 \mathrm{Ma}$ (concordant $\mathrm{U} / \mathrm{Pb}$ age on zircon), which implies that this acidic magmatic activity, while broadly contemporaneous with the mafic magmatism, cannot account for the granitoid dikes hosted by the Mont Collon gabbro. The latter could result from local remelting of the Arolla orthogneisses, in relation to the high heat flow generated by the emplacement of the mafic magma chamber, although no anatectic features have been observed in the present-day contact zone. Alternatively, melting might have occurred in the continental crust along the mafic magma feeding conduits, with subsequent injection of the melts upwards along tectonic discontinuities. Either way, the high initial ${ }^{87} \mathrm{Sr} /{ }^{86} \mathrm{Sr}_{\mathrm{i}}$ ratios of 0.70573 to 0.71005 and the low $\varepsilon \mathrm{Nd}_{\mathrm{i}}$ values of -1 to -6.6 of the granitoid dikes preclude an in situ origin by extreme differentiation of the mafic magmas.

The Mont Collon complex is definitely contemporaneous with the other Early Permian mafic bodies of the Variscan Alps and Corsica mentioned in the introduction (Fig. 1): Sondalo (280 \pm 10 and $300 \pm 12 \mathrm{Ma}$; Tribuzio et al. 1999), Braccia (281 \pm 19 Ma; Hansmann et al. 2001); Anzasca (288 +2/-4 Ma; called Sermenza gabbro, by mistake, in Bussy et al. 1998, see correction by Steck et al. 2001); Ivrea (285 +7/-5 Ma; Pin, 1986; 
$287 \pm 2 \mathrm{Ma}$ and $285 \pm 4 \mathrm{Ma}$; Quick et al. 2003); Levie (285.2 \pm $0.6 \mathrm{Ma})$ and Pila Canale $(279.2 \pm 0.6 \mathrm{Ma}$; the two latter in $\mathrm{Pa}-$ quette et al. 2003). The period of activity of this mafic magmatism of tholeiitic affinity is strikingly short all over this segment of the Variscan belt. This leads us to believe that there is a major tectonic control on the space and timing of this event, as initially suggested by Bonin (1988). The Variscan belt is characterized by major lineaments, such as lithospheric-scale transcurrent faults, some of which are sutures of accreted microcontinents (e.g. Stampfli et al. 2003). It is highly probable that Permian wrench tectonics reactivated these structures, allowing partial melting of the decompressed mantle along these faults and driving the magmas into the overlying continental crust. This process is well documented in the southern Alpine domain, where natural cross-sections through the lower, middle and upper continental crust are accessible to direct observation in different tectonic units. Mulch et al. (2002) document the syn-mylonitic emplacement of mafic and felsic melts 285$275 \mathrm{Ma}$ ago, along a 2-3 km wide shear zone, the CossatoMergozzo-Brissago Line, which forms the subvertical contact between the Ivrea-Verbano and Strona-Ceneri Zones, respectively. In their model, Mulch et al. (2002) consider the Cossato-Mergozzo-Brissago Line as a segment of an Early Permian, crustal-scale transcurrent shear zone that accommodated oblique-slip faulting and basin formation in the upper crust; and ductile thinning and exhumation of the lower crust. It is likely that such mega shear zones not only served as conduits for the ascent of melts through the continental crust, but also controlled the decompression and partial melting of the underlying mantle, source of the Permian mafic complexes in the future Austroalpine and Southern Alpine domains (Schaltegger \& Brack 2006).

The nature of the mantle source of the Permian mafic complexes is still unclear, as most of these magmas interacted with the continental crust to an unknown extent. For the Mont Collon complex, Monjoie (2004) favored a metasomatized lithospheric mantle to account for relatively low $\varepsilon \mathrm{Nd}_{280}$ Ma values between +3.2 and -0.6 . In the Ivrea gabbroic complex, the upper part exhibits initial whole-rock isotopic compositions indicating an origin from crustally contaminated liquids $\left(\delta^{18} \mathrm{O}\right.$ values up to $9.5 ;+2.9<\varepsilon \mathrm{Nd}_{290 \mathrm{Ma}}<+6.4$ and $0.7070<\left({ }^{87} \mathrm{Sr} /{ }^{86} \mathrm{Sr}\right)_{290 \mathrm{Ma}}$ $<$ 0.7086; Pin 1990; Voshage et al. 1990; Sinigoi et al. 1994). On the other hand, the lower part of the same complex is characterized by isotopic values close to the depleted mantle. In the same way, the Corsican lower crustal Santa Lucia di Mercurio layered mafic body displays a very large range of $\varepsilon \mathrm{Nd}_{280} \mathrm{Ma}$ values between -7.2 and +5.5 (Pin 1990), the lowest value being close to that of the country rock (Paquette et al. 2003). If the highest $\varepsilon \mathrm{Nd}_{\mathrm{i}}$ values are considered in each massif as closest to original values for the mantle melts before crustal contamination, they lie between +4.3 in Corsica (Cocherie et al. 1994) and +7.2 in Ivrea (Voshage et al. 1990), whereas the highest value for the Mont Collon main body is +3.2 (Monjoie 2004). Most authors have interpreted these relatively high $\varepsilon \mathrm{Nd}_{i}$ values as indicative of a somehow depleted mantle source. Her- mann et al. (2001) reached the same conclusion for the Braccia gabbro on the basis of trace-element modeling, whereas Schaltegger \& Brack (2006) suggest a mantle end-member isotopically comparable to the depleted subcontinental mantle, which was exhumed along the Adriatic passive margin during the Jurassic opening of the Tethys (Rampone et al. 1988; Müntener et al. 2004).

In this context, the interpretation of the ${ }^{40} \mathrm{Ar} /{ }^{39} \mathrm{Ar}$ age of $260.2 \pm 0.7 \mathrm{Ma}$ for the lamprophyric dikes in the Mont Collon complex is of particular interest. Indeed, these dikes have a high $\varepsilon \mathrm{Nd}_{i}$ value of +7.4 and a low initial ${ }^{87} \mathrm{Sr} /{ }^{86} \mathrm{Sr}_{i}$ ratio of 0.7029 , very different from the range of values measured in the main Mont Collon gabbroic body $\left(-0.6<\varepsilon \mathrm{Nd}_{\mathrm{i}}<+3\right.$ and 0.7045 $\left.<{ }^{87} \mathrm{Sr} /{ }^{86} \mathrm{Sr}_{i}<0.7057\right)$, but close to the depleted mantle pole mentioned above. If this age is interpreted as a cooling age, then the lamprophyric dikes might be subcontemporaneous with the main gabbroic body and could represent, from an isotopic point of view, the depleted mantle source. There are arguments in favor of this interpretation. First, no mafic magmatism is currently reported at $260 \mathrm{Ma}$ in the AustroalpineSouthern Alpine domains. Second, rocks very similar to the Mont Collon lamprophyric dikes have been described in the Braccia gabbro by Hermann et al. (2001). So-called Fe-Ti diorites $\left(42.80 \mathrm{wt} \% \mathrm{SiO}_{2}\right)$ occur as dikes and small bodies and their close association with massive Fe-gabbros led Hermann et al. (2001) to consider them cogenetic and contemporaneous with the main mafic body. These authors also emphasize the unusual chemical composition of these Fe-Ti diorites, which combine low $\mathrm{SiO}_{2}$ contents with high REE, Fe, Ti, $\mathrm{P}$ and $\mathrm{Zr}$ contents. In the absence of isotopic data, they suggest liquid immiscibility at high degree of differentiation or mixing of the mafic magma with a trace-element-enriched crustal partial melt as possible mechanisms to account for these peculiar rocks. The latter hypothesis cannot be considered for the Mont Collon lamprophyres, which display a purely mantellic isotopic signature.

Alternatively, if $260.2 \pm 0.7 \mathrm{Ma}$ is the intrusion age of the lamprophyres, as we argued above on the basis of field and textural relationships; then a time gap of about $25 \mathrm{Ma}$ separates the main magmatic activity recorded in the Permian mafic complexes of the Austroalpine/Southern Alpine domains from the local emission of small volumes of lamprophyric magma, restricted to the Mont Collon complex and the neighboring Matterhorn mafic body. In such case, the source of the lamprophyre magma could be the same as that of the 285-280 Ma old mafic complexes, as discussed above, or be located in a deeper level of the asthenosphere. The ambiguity on the intrusion age of the Mont Collon lamprophyres could be resolved with the $\mathrm{U} / \mathrm{Pb}$ dating of magmatic zircons, but none has been found so far in these rocks.

\section{Conclusion}

The Mont Collon mafic complex records two episodes of mantle-derived magmatic activity. The main period occurred 284.2 
$\pm 0.6 \mathrm{Ma}$ ago and resulted in the mid-crustal emplacement of a large body of layered gabbro of transitional affinity, originating in the subcontinental lithospheric mantle. This was accompanied by acidic back-veining from the continental countryrock. A few lamprophyric dikes, with contrasting isotopic signature, intruded subsequently the main gabbroic sequence. They display a ${ }^{40} \mathrm{Ar} /{ }^{39} \mathrm{Ar}$ age of $260.2 \pm 0.7 \mathrm{Ma}$, interpreted as the intrusion age rather than a cooling age on the basis of field and textural relationships. Two alternative sources might be invoked for these lamprophyric dikes: the same subcontinental lithospheric mantle which supplied the $284 \mathrm{Ma}$ mafic magmas provided this shallow mantle is of depleted type, or a deeper source in the asthenosphere.

The Mont Collon main body belongs to a series of 285-280 Ma-old mafic complexes, with similar chemical compositions, but variable isotopic signatures, mostly ascribed to variable degrees of crustal contamination. These Permian mafic complexes emplaced simultaneously in a restricted zone of the postVariscan continental crust, now exposed on Corsica and in the Austroalpine and Southern Alpine domains. This short pulse of consanguineous mafic magmas occurred in a delimited area. Its connection to volcano-sedimentary basins and to wrench tectonics suggests a strong control by transtensional lithospheric-scale fractures. These shear zones not only served as conduits for the magmas, but are believed to be the triggering factor of the mantle melting.

\section{Acknowledgements}

A. Von Quadt and the technical staff of the isotope group at ETH Zürich are kindly acknowledged for technical help in mineral separation and mass spectrometry. We thank an anonymous reviewer and the editor for their valuable comments, which helped clarifying the manuscript, as well as Isabelle Holloway for a careful checking of the English syntax. This study was financially supported by the Swiss National Science Foundation (project no. 20-050531.97), which is greatly acknowledged.

\section{REFERENCES}

Ballèvre, M., Kienast, J.R. \& Vuichard, J.P. 1986: La «nappe de la Dent blanche» (Alpes Occidentales): Deux unités austroalpines indépendantes. Eclogae geologicae Helveticae 79, 57-74.

Bill, M., Bussy, F., Cosca, M., Masson, H. \& Hunziker, J.C. 1997: High precision U-Pb and ${ }^{40} \mathrm{Ar} /{ }^{39} \mathrm{Ar}$ dating of an Alpine ophiolite (Gets nappe, French Alps). Eclogae geologicae Helveticae 90, 43-54.

Bistacchi, A., Dal Piaz, G.V., Massironi, M. \& Balestrieri, M.L. 2001: The Aosta-Ranzola extensional fault system and Oligocene - Present evolution of the Austroalpine-Penninic wedge in the northwestern Alps. International Journal of Earth Sciences 90, 654-667.

Bonin, B. 1988: From orogenic to anorogenic environments; evidence from associated magmatic episodes. Schweizerische Mineralogische und Petrographische Mitteilungen 68, 301-311.

Bussy, F. \& Cadoppi, P. 1996: U/Pb zircon dating of granitoids from the DoraMaira massif (western Italian Alps). Schweizerische Mineralogische und Petrographische Mitteilungen 76, 217-233.

Bussy, F., Venturini, G., Hunziker, J.C. \& Martinotti, G. 1998: U-Pb ages of magmatic rocks of the western Austroapline Dent Blanche-Sesia Unit. Schweizerische Mineralogische und Petrographische Mitteilungen 78, 163-168.
Bussy, F., Hernandez, J. \& von Raumer, J. 2000: Bimodal magmatism as a consequence of the post-collisional readjustment of the thickened Variscan continental lithosphere (Aiguilles Rouges-Mont Blanc massifs, western Alps). Transactions of the Royal Society of Edinburgh 91, 221233.

Cocherie, A., Rossi, P., Fouillac, A.M. \& Vidal, P. 1994: Crust and mantle contributions to granite genesis - A example from the Variscan batholith of Corsica, France, studied by trace-element and Nd-Sr-O isotope systematics. Chemical Geology 115, 173-211.

Dal Piaz, G.V., De Vecchi, G. \& Hunziker, J.C. 1977: The Austroalpine layered gabbros of the Matterhorn and Mont Collon - Dents de Bertol. Schweizerische Mineralogische und Petrographische Mitteilungen 57, 59-88.

Dal Piaz, G.V. 1993: Evolution of Austro-Alpine and Upper Penninic basement in the Northwestern Alps from variscan convergence to postvariscan extension. In: von Raumer, J.F., \& Neubauer, F. (eds): Pre-Mesozoic Geology in the Alps, Springer - Verlag, 327-344.

Dal Piaz, G.V. 1999: The Austroalpine-Piedmont nappe stack and the puzzle of Alpine Tethys. Memorie di Scienze Geologiche, Padova 51, 155-176.

Dalrymple, G.B., Alexander, E.C., Lanphere, M.A. \& Kraker, G.P. 1981: Irradiation of samples for ${ }^{40} \mathrm{Ar} /{ }^{39} \mathrm{Ar}$ dating using the Geological Survey TRIGA reactor. U.S.G.S. Professional Paper 1176, 55pp.

Gebauer, D. 1999: Alpine geochronology of the Central and Western Alps: new constraints for a complex geodynamic evolution. Schweizerische Mineralogische und Petrographische Mitteilungen 79, 191-208.

Hansmann, W., Müntener, O. \& Hermann, J. 2001: U-Pb zircon geochronology of a tholeiitic intrusion and associated migmatites at a continental crust-mantle transition, Val Malenco, Italy. Schweizerische Mineralogische und Petrographische Mitteilungen 81, 239-255.

Hermann, J., Müntener, O. \& Günther, D. 2001: Differentiation of mafic magma in a continental crust-to-mantle transition zone. Journal of Petrology 42, 189-206.

Innocent, C., Briqueu, L. \& Cabanis, B. 1994: Sr-Nd isotope and trace-element geochemistry of late Variscan volcanism in the Pyrenees: magmatism in post-orogenic extension? Tectonophysics 283, 161-181.

Jaffrey, A.J., Flynn, F.K., Glendenin, L.E., Bentley, W.C. \& Essling, A.M. 1971: Precision measurements of half-lives and specific activities of ${ }^{235} \mathrm{U}$ and ${ }^{238}$ U. Physical Review C4, 1889-1906.

Krogh, T.E. 1973: Improved accuracy of U/Pb zircon ages by the creation of more concordant system using an air abrasion technique. Geochimica and Cosmochimica Acta 46, 637-649.

Leake, B.E., Woolley, A.R., Arps, C.E.S., Birch, W.D., Gilbert, M.C., Grice, J.D., Hawthorne, F.C., Kato, A., Kisch, H.J., Krivovichev, V.G., Linthout, K., Laird, J., Mandarino, J.A., Maresch, W.V., Nickel, E.H., Rock, N.M.S., Schumacher, J.C., Smith, D.C., Stephenson, N.C.N., Ungaretti, L., Whitaker, E.J.W. \& Guo, Y. 1997: Nomenclature of amphiboles; report of the subcommittee on amphiboles of the International Mineralogical Association, Commission on New Minerals and Mineral Names. Canadian Mineralogist 35, 219-246.

Ludwig, K.R. 1998: Isoplot: a plotting and regression program for radiogenicisotope data. U.S.G.S., Open File Report 91-445, 43 pp.

Martinotti, G. \& Hunziker, J.C. 1984: The Austroalpine system in the Western Alps: a review. Memorie della Societa di Geologia Italiana 29, 233-250.

McDougall, I. \& Harrison, T.M. 1988: Geochronology and thermochronology by the ${ }^{40} \mathrm{Ar} /{ }^{39} \mathrm{Ar}$ method. Oxford Monograph on Geology and Geophysics $\mathrm{n}^{\circ} 9,212 \mathrm{pp}$.

Monjoie Ph., Bussy F., Schaltegger U., Lapierre H., Pfeifer H.R. 2002: Permian mafic rocks in the Alps: a post-orogenic mantle melting event illustrated by the Mont Collon-Matterhorn intrusion (Austroalpine Dent Blanche nappe). Journal of Conference Abstracts, EUG 11, Strasbourg 6, 475 .

Monjoie P. 2004: The Mont Collon mafic complex (Austroalpine Dent Blanche nappe): Permian evolution of the western European mantle. PhD thesis, Universities of Lausanne \& Grenoble, $156 \mathrm{pp}$ (http://tel.ccsd.cnrs.fr/tel-00006439).

Monjoie, P., Bussy, F., Lapierre, H. \& Pfeifer, H.-R. 2005: Modeling of in situ crystallization processes in the Permian mafic layered intrusion of Mont Collon (Dent Blanche nappe, western Alps). Lithos 83, 317-346. 
Mulch, A., Rosenau, M., Doerr, W. \& Handy, M.R. 2002: The age and structure of dikes along the tectonic contact of the Ivrea-Verbano and StronaCeneri zones (Southern Alps, northern Italy, Switzerland). Schweizerische Mineralogische und Petrographische Mitteilungen 82 1, 55-76.

Müntener O., Desmurs L., Pettke T., Meier M. \& Schaltegger U. 2004: Formation of fertile mantle in embryonic ocean basins controlled by melt/rock reaction. Earth and Planetary Science Letters 221, 239-308.

Paquette, J.-L., Ménot, R.-P., Pin, C. \& Orsini, J.-B. 2003: Episodic and shortlived granitic pulses in a post-collisional setting: evidence from precise $\mathrm{U}-\mathrm{Pb}$ zircon dating through a crustal cross-section in Corsica. Chemical Geology 198, 1-20.

Pin, C. 1986: Datation U-Pb sur zircons à 285 Ma du complexe gabbro-dioritique du Val Sesia-Val Mastallone et âge tardi-hercynien du métamorphisme granulitique de la zone Ivrea-Verbano (Italie), Comptes rendus de l'Académie des sciences, Série II 303, 827-830.

Pin, C. 1990: Variscan oceans; ages, origins and geodynamic implications inferred from geochemical and radiometric data. Tectonophysics 177 , 215-227.

Poitrasson, F., Pin, C., Duthou, J.-L. \& Platevoet, B. 1994: The size-isotopic evolution connection among layered mafic intrusions: clues from a $\mathrm{Sr}-\mathrm{Nd}$ isotopic study of a small complex. Journal of Geophysical Research 99/B5, 9441-9451.

Quick, J.E., Sinigoi, S. \& Mayer, A. 1994: Emplacement dynamics of a large intrusion in the lower crust, Ivrea-Verbano, northern Italy. Journal of Geophysical Research 99/B11, 21559-21573.

Quick, J.E., Sinigoi, S., Snoke, A.W., Kalakay, T.J., Mayer, A. \& Peressini, G. 2003: Geologic map of the southern Ivrea-Verbano Zone, Northwestern Italy. Geologic Inverstigations Series map I-2776; U.S.G.S.; map + pamphlet, $22 \mathrm{pp}$.

Rampone, E., Hofmann, A.W. \& Raczek, I. 1998: Isotopic contrasts within the Internal Liguride ophiolite (N. Italy): the lack of a genetic mantle-crust link. Earth and Planetary Science Letters 163, 175-189.

Renne, P.R., Swisher, C.C., Deino, A.L., Karner, D., Owens, T. \& de Paolo, D. 1998: Intercalibration of standards, absolute ages and uncertainties in ${ }^{40} \mathrm{Ar}{ }^{\beta 9} \mathrm{Ar}$ dating. Chemical Geology $145,117-152$.

Rubatto, D., Gebauer, D. \& Fanning, M. 1998: Jurassic formation and Eocene subduction of the Zermatt-Saas-Fee ophiolites; implications for the geodynamic evolution of the Central and Western Alps. Contributions to Mineralogy and Petrology 132, 269-287.

Schärer, U. 1984: The effect of initial ${ }^{230} \mathrm{Th}$ disequilibrium on young U-Pb ages: the Makalu case, Himalaya. Earth and Planetary Science Letters 67, 191-204.

Schaltegger, U. 1997: Magma pulses in central Variscan Belt; episodic melt generation and emplacement during lithospheric thinning. Terra Nova 9, 242-245.

Schaltegger, U., Fanning, C.M., Gunther, D., Maurin, J.-C., Schulmann, K. \& Gebauer, D. 1999: Growth, annealing and recrystallization of zircon and preservation of monazite in high-grade metamorphism; conventional and in-situ U-Pb isotope, cathodoluminescence and microchemical evidence. Contributions to Mineralogy and Petrology 134, 186-201.
Schaltegger, U., Desmurs, L., Manatschal, G., Müntener, O., Meier, M., Frank, M. \& Bernoulli, D. 2002: From a rifted continental margin to a slow spreading system: field and isotopic constraints. Terra Nova 14, 156-162.

Schaltegger, U. \& Brack, P. 2007: Crustal-scale magmatic systems during intracontinental strike-slip tectonics: $\mathrm{U}, \mathrm{Pb}$ and $\mathrm{Hf}$ isotopic constraints from Permian magmatic rocks of the Southern Alps. International Journal of Earth Sciences DOI 10.1007/s00531-006-0165-8.

Sinigoi, S., Quick, J.E., Clemens-Knott, D., Mayer, A., Demarchi, G., Mazzucchelli, M., Negrini, L. \& Rivalenti, G. 1994: Chemical evolution of a large mafic intrusion in the lower crust, Ivrea-Verbano Zone, northern Italy. Journal of Geophysical Research 99/B11, 21575-21590.

Stampfli, G.M., Borel, G.D., Marchant, R. \& Mosar, J. 2002: Western Alps geological constraints on western Tethyan reconstructions. In: Rosenbaum, G. \& Lister, G.S.: Reconstruction of the evolution of the AlpineHimalayan Orogen (2002), Journal of the Virtual Explorer 8, 77-106.

Steck, A., Epard, J.L., Escher, A., Gouffon, Y. \& Masson, H. 2001: Carte géologique des Alpes de Suisse occidentale 1:100.000. Carte géologique spéciale $\mathrm{n}^{\circ} 123$, notice explicative. Office Fédéral des Eaux et de la Géologie (Berne).

Steiger, R.H. \& Jaeger, E. 1977: Subcommission on geochronology; convention on the use of decay constants in geo- and cosmochronology. Earth and Planetary Science Letters 36, 359-362.

Tribuzio, R., Thirlwall, M.F. \& Messiga, B. 1999: Petrology, mineral and isotope geochemistry of the Sondalo gabbroic complex (Central Alps, Northern Italy): implications for the origin of post-Variscan magmatism. Contributions to Mineralogy and Petrology 136, 48-62.

Venturini, G. 1995: Geology, geochemistry and geochronology of the inner central Sesia Zone (Western Alps - Italy). Mémoires de Géologie Lausanne, $25,148 \mathrm{pp}$.

Venturini, G., Martinotti, G., Armando, G., Barbero, M. \& Hunziker, J.C. 1994: The Central Sesia Lanzo Zone (Western Italian Alps): new field observations and lithostratigraphic subdivisions. Schweizerische Mineralogische und Petrographische Mitteilungen 74, 115-125.

Voshage, H., Hofmann, A.W., Mazzucchelli, M., Rivalenti, G., Sinigoi, S., Raczek, I. \& Demarchi, G. 1990: Isotopic evidence from the Ivrea Zone for a hybrid lower crust formed by magmatic underplating. Nature, 347, 731-736.

Manuscript received 12 August, 2005

Revision accepted 10 August, 2006

Published Online First April 18, 2007

Editorial handling: Martin Engi 
